\title{
Ускладнення пункційної вертебропластики
}

\author{
Яворський О. А., Ломакін А. М., Свєтлицький В. П. \\ Центр реконструктивної та відновлювальної медицини (Університетська клініка), Одеський національний \\ медичний університет, Одеса, Україна
}

Мета. Покращити результати пункційної вертебропластики як методу мінімально інвазивного лікування больового синдрому при травматичних та патологічних переломах хребта.

Матеріали та методи. Виконано аналіз результатів лікування хворих в Університетській клініці ОНМедУ за період з 2013 по 2018 рік. Загалом проаналізовано випадки лікування 134 хворих та виконання вертебропластики 214 хребців. 3 приводу гострої травми лікувалися 21 хворих (23 хребці), $з$ приводу патологічних переломів на фоні остеопорозу проліковано 58 хворих (104 хребці), з приводу пухлинного ураження хребта - 55 хворих (87 хребців). Післяопераційний контроль виконувався інтра- та післяопераційно за допомогою флюороскопії 3 використанням С-дуги i, на наступний день після операції, методом комп'ютерної томографії. Виконано аналіз кількості й структури післяопераційних ускладнень та ї вплив на якість життя хворих за шкалами ВАШ (візуальна аналогова шкала болю) та FIM (functional independence measure scale).
Також виконано порівняльний аналіз специфічності методів рентгенологічного контролю екстравертебрального розповсюдження полімеру (кісткового цементу).

Результати. Жодне з виявлених ускладнень не мало суттєвого клінічного впливу на перебіг захворювання. Кількість випадків екстравертебрального розповсюдження цементу, що не проявлялись клінічно, які були виявлені під час комп'ютерної томографії, значно перевищувала рентгенологічні дані. В порівнянні: 18,7 \% та 4,7 \% випадків ускладнень виявлені за допомогою комп'ютерної томографії та рентгенографії. Єдиний випадок емболії дрібних гілок легеневої артерії був виявлений випадково під час післяопераційного дослідження грудного відділу хребта.

Висновки. Аналіз літературних даних та власних отриманих результатів дозволяе пропонувати використання комп'ютерної томографії в післяопераційному періоді, як найбільш чутливого методу діагностики післяопераційних ускладнень пункційної вертебропластики. 